\title{
Role of Multimedia Tutorials in Distance Education
}

\author{
Nasrullah \\ Dowling College, New York, USA
}

\begin{abstract}
The researcher conducted the study in Allama Iqbal Open University Islamabad, Pakistan to learn the effect of multimedia tutorial on learning in distance education programs. One hundred and twenty graduate students were selected as a sample for the research. The researcher divided the sample into two groups, experimental group and control group. Students of both groups used conventional printed learning material of the university during their study. However the experimental group, along with print material, benefited from multimedia tutorial of educational psychology (edupsych840). Results showed that students in the experimental group performed better than the students in the control group. The researcher found that multimedia tutorial increased learning. The study recommended that multimedia tutorial techniques may be used face- to- face tutorial meeting between distance learners and teachers in distance education programs to enhance learning of students.
\end{abstract}

\section{Introduction}

Distance education is a method of teaching students off-campus, at a distance and with a flexible schedule. The distance education is a very broad term and covers all the traditional and technological means to educate the masses. Distance education systems use correspondence, audio or videotapes, or both, telecommunication and compressed video and audio systems for instructional purposes [3].

The early distance education (DE) systems used print material for instruction-and correspondence courses was the most common delivery method of course material to distant learner. However, presently the DE systems use information and communication technologies (ICT) along with the above mentioned method for instructional purpose. The ICT includes web based instruction, online (chat) communication, offline (e-mail) communication, video conferencing, and computer assisted instruction. The multimedia software available on CD-ROM plays a powerful role in labs, lectures, tutorial, and project works [15].

Koehler and Blair [8] have classified methods of distance education into two groups: Synchronous and Asynchronous delivery methods. In synchronous mode, instructor and learners interact with each other in real time (same time). A traditional classroom, two way closed circuit TV, and video conferencing are examples of synchronous methods of learning. On the other hand in Asynchronous method creation and delivery of instruction and the consumption of instruction occur at different times and usually at different places. Correspondence courses, audio video tapes, and courseware packages placed on $\mathrm{CD}$ ROM or offered through a website are examples of asynchronous mode of instructions delivery.

Allama Iqbal Open University is the largest university in Pakistan that offers a variety of distance learning degree programs at undergraduate and graduate levels. The university uses different means to bridge the gap between its teachers and students and to enhance learning of. In Allama Iqbal Open University case, usually, method of instruction is print material which is sent to the learners through mail. Learning is also supported by TV/Radio programs and optional face to face meetings with the instructor. Besides these methods, OLIVE (open learning institute of virtual education) has been established since 2000. It has three models for delivery of instructions. In model A online assignment submission/checking, online special/guest lecture, and multimedia course streaming are provided. The second delivery model (model B) focuses on the students who have access to the internet. Internet based live sessions with teacher through OLIVE LMS is the main feature of this model. While in model C, students are provided self-learning multimedia courseware and reference material on CDs. Students can study material at home, office or any place of their choice. Moreover model $\mathrm{B}$ and model $\mathrm{C}$ can be combined to make a hybrid model for instruction delivery [15].

University of Idaho has classified various learning methods into four groups.

Each has its own strengths and limitations.

\section{- $\quad \mathrm{VOICE}$}

In this method the gap between the learner and teacher is bridged by simple telephone calls, audio conferencing, audio tapes and audio CD-ROM

- VIDEO

Instructional video tools include slides, films, video tape, and interactive video,

\section{- DATA OR \\ COMPUTER-BASED} SYSTEMS.

Computer is a dynamic machine which has the capabilities of storing, processing, and communication of data, so the learner can use 
computer for chatting, blog, e-mail, or for watching video clips.

Multimedia programs have many advantages over conventional print materials. Teaching through computers results in active learning through interaction with computer based material, self-paced and individualized instruction, and presentation of multiple real time simulations [16].

Many researchers have been conducted research to determine effectiveness of multimedia tutorials. One such research was conducted by Asan in Karadeniz Technical University, in Turkey in 20002001 [1]. In this research two groups of teachers were separately taught with traditional lecture method and multimedia. The findings of the research showed that the average score in multimedia group was higher in terms of depth of understanding, accuracy, rich supporting detail, organization, scope and reflection [1].

Advantages of the multimedia tutorials are summarized in the following points.

1. Allow self-paced instruction.

2. May incorporate text, graphics, video, and audio.

3. Allow high level of interactivity

4. Provide written record of discussion and instruction

5. Are cost effective

6. flexible in format and distribution

7. World wide access

\section{- $\quad$ PRINT}

The first and mostly used distance learning methods is print in. It is the cheapest source of communication used for correspondence courses. Print formats include textbooks, study guides, workbooks.

Interactive multimedia learning is a new paradigm of learning. Multi-media tutorials deliver instructions to learners in a combination of various forms like, text, audio, video, animations and simulations. Multimedia describe a computer based instruction which includes text, audio, moving pictures, and still pictures. According to Tannenbaum [17] "Multimedia is defined as an interactive, computer mediated presentation that includes at least two of these elements Text, sound, still graphics images, motion graphics images and animation." These tutorials consist of a user-friendly interface which provides control of navigation to learners [22]. Kruse and Kiel [9] has defined multimedia slightly different from that of Tannenbaum. They defined multimedia as CD-ROM. They say "CD-ROM provide a more engaging learning experience with text, audio, video, and animations all used to convey information......the set of multiple media means that learning is optimized."

The generation of twenty first century has some distinct characteristics that set them apart from the previous generation. Technology has changed the lives of people of this generation. Most of the people of this generation have access to computers, video games, digital music players, video cams, cell phones, and all the other toys and tools of this digital age. This technology rich culture has influenced the skills and interests of the people of the digital age. The students of this age are dependent on communication technologies for accessing information and for interacting with others [2].

Personal computers and laptops and other digital devices have changed today's learning style. Personal computers, laptops, cell phones, and other digital devices could be networked together. They are getting cheaper and are becoming smaller and more portable [4]. The use of this technology has created a new term of Ubiquitous Learning

Use of computer and internet in education is very common. It has generated many new terms like elearning, online learning, Ubiquitous learning etc. Now it is possible to deliver computer based tutorial to a large number of students through systems distance learning [5]. Computer can be used to access information on CD- ROM, can be used to prepare material for teaching. It provides access to large amount of resources for teachers.

The role of ICT in education has been investigated by some organizations. According to a report of UNESCO [21] "A variety of computerbased technologies have been used including the distribution of sample lesson plans on CD-ROMS, setting up exchanges by computer conference between teachers' colleges, encouraging the interactive use of computer-based learning materials, encouraging the use of web-based materials, and using computer conferencing to encourage discussion among learners".

Computer based instruction provide high-interest drill and practice programs to support learning, especially for students requiring skill remediation. Student evaluation shows that the new media of conferencing, e-mail, Web sites and electronic resources via library databases and the Internet are helpful in effective learning. An annual survey (conducted by UNECO) of different courses shows that Open University (OU) students in different faculties use these media in their courses. According to the survey findings [18]:

1. Science courses have always made good use of software supplied on CD and now DVDs, and 
over 40 per cent of their students rated such materials as very helpful.

2. Science students, however, gave very low helpfulness ratings to audio $\mathrm{CD}$

3. 60 per cent of language students rated audio CD as very helpful

4. 40 per cent in health and social care, arts and education rated audio $\mathrm{CD}$ as very helpful.

Computer based instruction provides a significant opportunities to improve the quality of teaching profoundly and cost effectively. There is 50\% increase in the retention, a significant improvement in the learning rate, an increase in course completion, and a decrease in the overall cost of education [7].

Some authors use the term e-learning which covers all forms of leaning in which computer is an essential component. Bandon Hall defines e-learning as instruction delivered electronically wholly by a web browser, through internet or intranet, or through CD-ROM or DVD multimedia platforms

When contents are delivered via CD-ROM or DVD it is referred to as computer based training. The use of WWW, CD-ROM, and computer based learning resources in the process of learning, anywhere, are various forms of e-learning.

The following benefits of e-learning were identified by Choy in 2007:

\section{Enhances learning}

\section{Improves engagement}

3. Extends experiences in empowers the learner to take responsibility for scheduling and managing learning journey.

What is the role of multimedia tutorial in education and especially in distance education? Is its role effective? Before moving forward let's find answers to these questions. Multimedia tutorials have many advantages. While learning through multimedia students actively interact with learning material. It enables students to learn at their own pace. Individualized instructions and presentation of multiple real time simulations are the main features of these tutorials [10].

Many researchers have role and effectiveness of multimedia tutorials in learning. Asan in Karadeniz Technical University, in Turkey in 2000-2001 conducted a research to compare two methods of instructions, multimedia and lecture [1]. The findings of the research showed that average score in multimedia group was higher. They were better than the lecture group in depth of understanding, accuracy, rich supporting detail, organization, scope, and reflection [1]

Every Learning theory dictates some new changes in teaching/learning styles, situations, media, and methods. Developmental psychologists argue that significant learning occurs only in purposeful context and through active learning. Such type of learning is called situated learning. It is creation of an environment where students are actively participating in the exploration and analysis. Multimedia tutorial provide such environment where situated learning takes place [1].

Multimedia based instructions, like other teaching learning methods need support of a theory. Cognitive theory of multimedia learning supports and explains multimedia learning. According to this theory human information system consists of two separate channels, auditory channel and visual channel. Auditory channel is for the processing of auditory input and verbal representations. Visual channel is for the processing of visual input and pictorial representations. The theory further explains that the meaningful learning occurs after a cognitive process in auditory and visual channels. The cognitive process includes paying attention to the presented material, organizing the presented material into a coherent structure, and integrating the presented material with existing knowledge [10]. Figure 1 is the pictorial representation of this theory.

After discussing the multimedia tutorial and its supporting learning theory now let's discuss role of multimedia tutorial in distance education. Multimedia tutorial enhances effectiveness of distance education. It has the ability to be delivered to the distance students over a CD-ROM or a DVD, or through internet.

The term distance education indicates that there is a distance between learner and teacher. In distance education a significant proportion of the teaching is conducted by someone removed in space and/or time from the learner [20]. Distance education is a deliberate process and it consists of all types of formal instruction that are conducted when teachers and learners are not located at the same place [6]. Unlike learner of formal education distance learners use some means to overcome the distance between them and distant teacher.

The face-t- face meetings are used to overcome many of the flaws of print material. It provides a two-way real time interaction. But increase in faceto-face tutorial meetings may decrease the benefits of distance education. It also violates the principle of flexibility of distance education. According to Randy [14] focus in the study of distance education has shifted to emerging communication technology, 


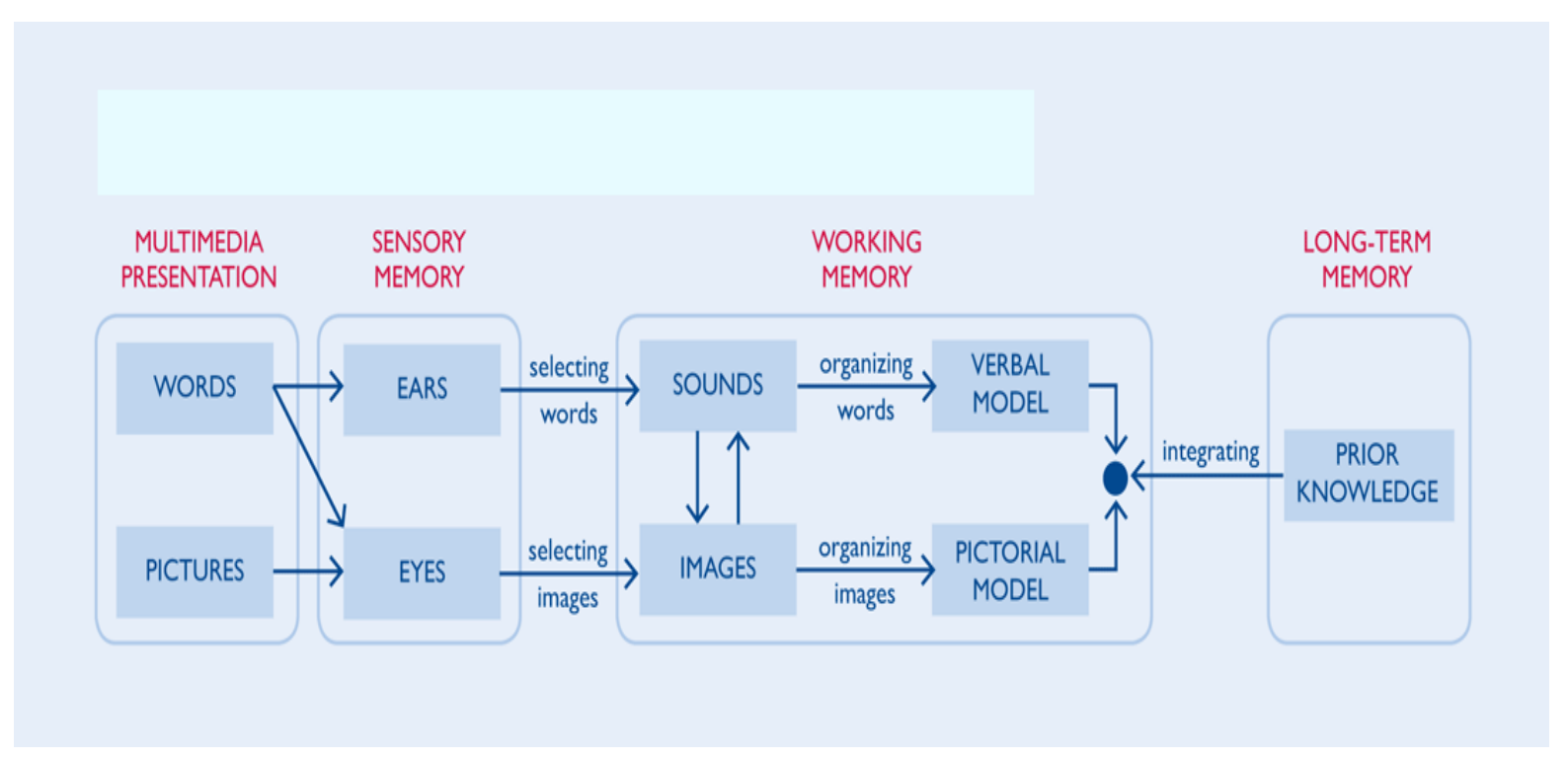

Figure 1. Depiction of cognitive theory of multimedia learning [10]

The computer mediated instruction is emerging as new way to add interactivity to the distance education. A lot of text as well as audio and video data can be stored on a CD-ROM. Students may use it in learning anywhere, any time. The multimedia software available on CD-ROM plays a powerful role in labs, lectures, tutorial, and project works [13].

In this digital era teaching learning activities are now not limited to a class room. Technology has changed the lives of people of this generation. The people of this generation have access to computers, video games, digital music players, video cams, cell phones, and all the other toys and tools of this digital age. This technology rich culture has influenced the skills and interests of the people of the digital age. The students of this age most of the time use communication technologies for accessing information and for interacting with others.

Desktop computers, laptops and other digital devices have changed today's learning style. Personal computers, laptops, cell phones, and other digital devices could be networked together. They are getting cheaper and are becoming smaller and more portable [3].

Use of computer and internet in education is very common. The use of this technology has created many new terms like e-learning, online learning, Ubiquitous learning etc. Now it is possible to deliver multimedia tutorial to a large number of students through systems distance learning [4]. ICT could be used to access a large amount of resources.

The role of multimedia in education has been investigated by individual researchers as well as by organizations. According to a report of UNESCO [21] "A variety of computer-based technologies have been used including the distribution of sample lesson plans on CD-ROMS, setting up exchanges by computer conference between teachers' colleges, encouraging the interactive use of computer-based learning materials, encouraging the use of web-based materials, and using computer conferencing to encourage discussion among learners".

Multimedia based instruction provides highinterest drill and practice programs to support learning, especially for students requiring skill remediation. Student's evaluation shows that the new media of conferencing, e-mail, Web sites and electronic resources via library databases and internet are helpful in effective learning. Many surveys of different courses show that OU (Open University) students in different faculties use these media in their courses, like these [16].

1. Science courses have always made good use of software supplied on CD and now DVDs, and over 40 per cent of their students rated such materials very helpful.

2. Science students, however, gave very low helpfulness ratings to audio $\mathrm{CD}$.

3. Sixty per cent $(60 \%)$ of language students rated audio $\mathrm{CD}$ very helpful.

4. Forty per cent (40\%) in health and social care, arts and education rated audio CD very helpful [16].

Multimedia based instruction provides significant opportunities to improve the quality of teaching profoundly and cost effectively. There is $50 \%$ increase in the retention, a significant improvement 
in the learning rate, an increase in course completion, and a decrease in the overall cost of education [6].

Multimedia based education requires transformation of paper based contents to digital format. This new paradigm provides new learning environment. The conventional paper based contents may not fit to this environment. In the development of multimedia tutorial efforts are made to design and develop such contents for the new learning environment. For this paradigm shift transformation of education, especially distance education is necessary.

The distance educational institutions (open universities) prepare interactive multimedia programs to overcome the shortcomings of the print material. Bork [2] suggested that natural way, to deliver multimedia tutorial, is through distance education. The tutorial can be used by distance learner anywhere and at any time. These tutorials motivate learners which is important for successful distance teaching. In CD ROM a distant teacher can pack all the learning material (text, graphs, sound, videos, models and pictures), he wants to present learners for learning.

In Allama Iqbal Open University case, the usual method of instruction is print material which is sent to the learners through mail. Learning is also supported by TV/Radio programs and face to face meetings. Besides these methods, OLIVE (Open Learning Institute of Virtual Education) has been established since 2001. It has three models for delivery of instructions. In model A - online assignment submission/checking, online special/guest lecture, and multimedia course streaming are provided. The second delivery model (model B) focuses on the students who have access to the internet. Internet based live sessions with teacher through OLIVE LMS is the main feature of this model. While in model $\mathrm{C}$ students are provided self-learning multimedia courseware and reference material on CDs. Students may study material at home. Moreover model B and model $\mathrm{C}$ can be combined to make a hybrid model for instruction delivery [13].

The tutorial used in this study was developed for educational technology 840 offered by Allama Iqbal Open University Islamabad, Pakistan to MA (education)/M.Ed. students. The Study Guide 840 second edition is supported by the printed Allied Material. Both the study guide + Allied are mailed to the students for study of educational psychology. Study Guide consists of nine units. The Nature of Educational Psychology, Growth and Development During Childhood and Adolescence-I, Growth and Development During Childhood and Adolescence-II, Personality, Human Needs, Learning, Motivation, Intelligence, Psychological testing
The book has some shortcomings which are.

1. No image or diagram is used in the guide to support learning.

2. It has no support of audio video electronic program.

3. The Allied Material provided is lengthy and difficult.

To overcome these short comings an interactive multimedia tutorial was developed. The tutorial consists of five units. Figure 2 shows the five units and sub menu of the first unit.

The following are details of the 5 units and topics included in each unit.

\section{Unit 1 the Nature of Educational Psychology}

1. Introduction

2. Definition of psychology

3. Definition of educational psychology

4. Methods of educational psychology

(scientific method)

5. Clinical method

6. Psychophysical method

7. Experimental method

8. Quiz

\section{Unit 2 Growth and Development}

1. Introduction

2. Nature of growth and development

3. Development and education

4. Mental growth and development

5. Language development

6. Physical growth and motor development

7. Social development

8. Moral development

9. Adolescence and development

10. Emotional development

11. Quiz

\section{Unit 3 Personality}

1. Introduction

2. Nature of personality

3. Theories of personality (Jung's theory of personality)

4. Trait theory of personality

5. Eysenck's theory of personality

6. Psycho analytical theory of Freud

7. Humanistic theory of personality

8. Stages of personality

9. Intelligence

10. Evaluation of intelligence definitions

11. Intelligent behavior

12. Theories of intelligence

13. Quiz 


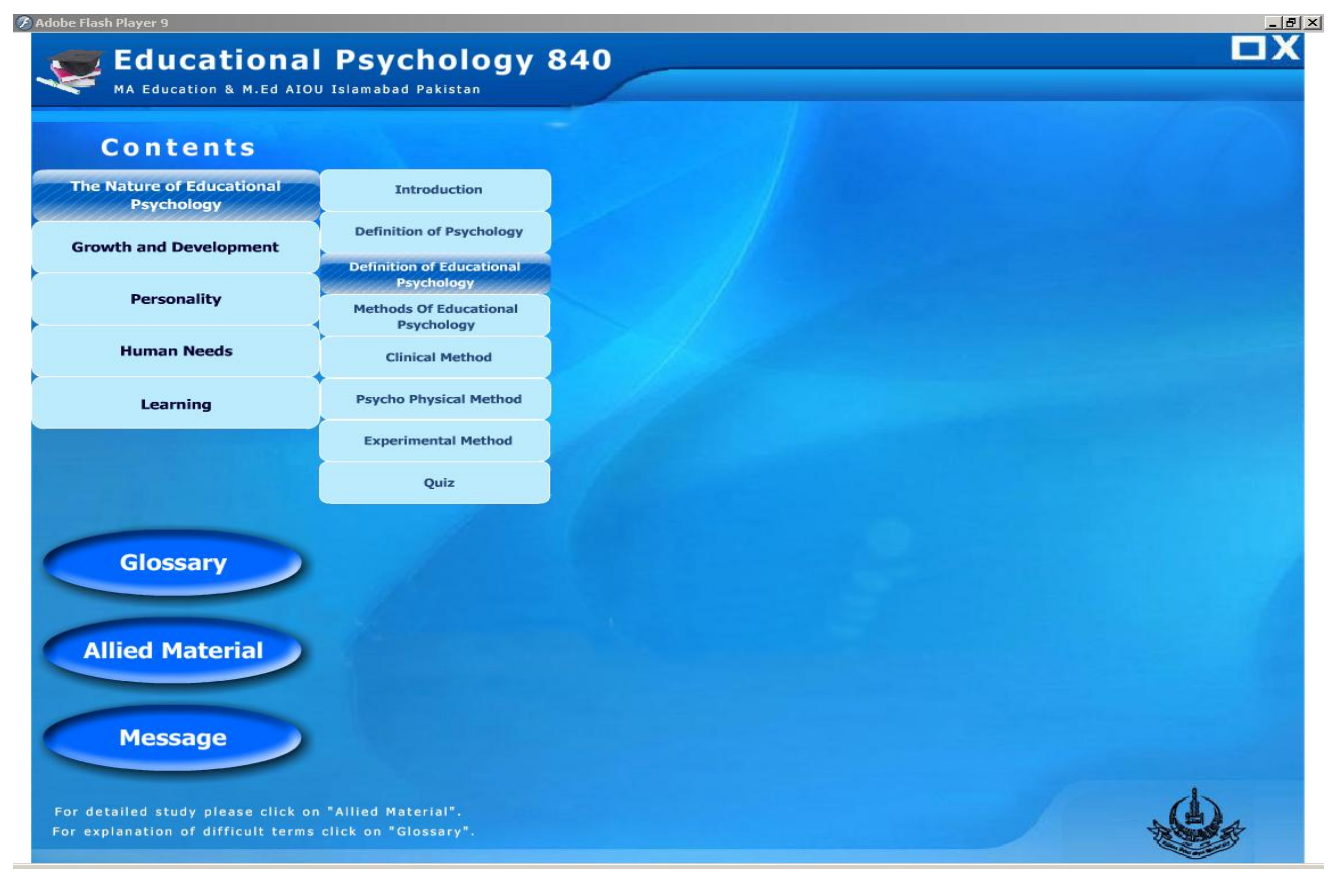

Figure 2. Menu and sub menu of the tutorial developed for educational psychology (840)

\author{
Unit 4 Human Needs \\ 1. Introduction \\ 2. Concept of needs \\ 3. Physical needs \\ 4. Psychosocial needs part I \\ 5. Psychosocial needs part II \\ $6 . \quad$ Interest \\ 7. Motivations \\ 8. Types of motives \\ 9. Types of motivations \\ 10. Quiz
}

\section{Unit 5 Learning}

1. Introduction

2. What is learning?

3. Learning theories (trial and error theory)

4. Theory of behavior

5. Gestalt theory of learning

6. Lewin's field theory

7. Tolman's theory of learning

8. Bruner's model of concept learning

9. Piaget Model of concept learning

10. Gagne conditions of learning

11. Quiz

First topic of each unit is 'introduction', which contains introduction to the unit and learning objectives of the unit. Each unit have quiz at end. The quiz provides 10 multiple choice questions. The tutorial contains 5 units while the study guide for educational psychology 840 consists of 9 units. Important topics from the remaining 4 unit were included in the 5 units, while some of the topics remained untouched due to shortage of time.

\section{Objectives of the Study}

- To assess effectiveness of multimedia tutorial in learning.

- To explore the role of multimedia tutorial in distance education.

\subsection{Research Design}

This study has used a post-test only control group design. Two groups (control group and experimental group) were formed. For an experimental study 30 numbers of subjects in each group is considered enough. However, in distance education usually the dropout rate is high and also by increasing size of a sample generalizability of a research can be increased. Therefore each group was assigned 60 students. A random sample of 140 students was taken from a population of 401 students. Control group was assigned 60 students randomly, while experimental group was assigned 80 students randomly. The assignment of 20 extra students to the experimental group was to ensure that all the members of experimental group have access to personal computers, and have watched the tutorial CD completely. At the time of delivery of tutorial CDs 12 students refused to take CD because they were having no access to a computer. At the end of semester when a questionnaire survey about the components of the tutorial was conducted, the researcher realized that 6 students did not study the tutorial sufficiently. Two more students were dropped from the experimental group to equalise 
both the groups. At the end each group was having 60 students.

Post-test only research design was used for this study for some reasons. First unlike formal system students in distance education study the learning material individually usually at home. Second it was difficult to arrange pre-test for the scattered students of experimental and control group. Third the research was related to the field of distance education and it was essential to maintain distance education environment throughout the research. In these circumstances the post-test only was more appropriate design to be used. The terminal examination conducted by the university at the end of the semester was considered the post test for this experimental research.

\section{Research Variables}

A description of research variables is presented as follows.

\section{i. Independent variable}

Independent variable was multimedia tutorial given to the experimental group.

\section{ii. Dependent variables}

The dependent variable was the achievement of grades of students in the terminal examination of AIOU.

\section{iii. Control variables}

Following variables were held constant for the duration of the experiment

$\begin{array}{ll}\text { a. } & \text { Length of the lesson } \\ \text { b. } & \text { Size of the group } \\ \text { c. } & \text { Content and sequence of content } \\ \text { d. } & \text { Print material (study guides) } \\ \text { rovided by AIOU }\end{array}$

\section{iv. Uncontrolled variables}

These were variables that were not manipulated by the researcher. In this research, uncontrolled variables were:

$\begin{array}{ll}\text { a. } & \text { Age of students } \\ \text { b. } & \text { Social status of the students } \\ \text { c. } & \text { IQ of students } \\ \text { d. } & \text { Study habits of students } \\ \text { e. } & \text { Previous achievements of students } \\ \text { f. } & \text { Pace of the study of the students } \\ \text { g. } & \text { Place and time of the study of the students. }\end{array}$

\section{Research Instruments}

As the study was to measure the effects of the tutorial on the achievement of grades so the students' marks achieved in the terminal examination were taken as experimental data. The examination department of AIOU reports results of examination in detail. It includes assignment marks, examination marks, conflated marks, and grade for each subject for which a student has appeared in the examination. Grades (A, B, C, D) are decided according to conflated marks which include both the assignment marks and examination marks. As the assignments are done by the students at their homes and are less reliable, therefore I decided to take examination marks for analysis. T-test was used to test the null hypothesis.

\section{Data Analysis}

It was an experimental research in which difference between two methods of instruction was studied. As $n=60 n>30 \quad(n$ is the size of experimental or control group) therefore for testing of hypothesis t-test was used.

It has been stated in the proceeding section that the final examination held by the university was used as base. Therefore grades in the examination were used as data which were collected from the controller of examinations AIOU and analyzed using Student's t-distribution.

Score tables were used for analysis. Mean (defined as sum of all observations divided by the number of observations symbolically $\sum \mathrm{Xi} / \mathrm{n}$ ), Variance (defined as the average of the squared deviations from the mean, symbolically $\sigma 2=\sum$ (xi x) $2 / n$ ), Standard Deviation (positive square root of the variance, symbolically $\left.\sigma=\operatorname{SQRT}\left(\sum(x i-x) 2 / n\right)\right)$, and t-test were calculated for both control group and experimental group on marks achieved in the terminal examination. The generally accepted 0.05 significance level was chosen for this study.

Table 1. Analysis of scores of Experimental and Control Groups in final examination

\begin{tabular}{|l|l|l|l|l|l|}
\hline Group & Mean & S.D. & Variance & t-value & \\
\hline & & $\begin{array}{l}\text { Calculated } \\
\text { Value }\end{array}$ & $\begin{array}{l}\text { Tabulated } \\
\text { Value }\end{array}$ \\
\hline $\begin{array}{l}\text { Experimental } \\
\mathrm{N}=60\end{array}$ & 55.78 & 5.58 & 31.12 & $6.2 \mathrm{df}=118$ & 1.9 \\
\hline $\begin{array}{l}\text { Control } \\
\mathrm{N}=60\end{array}$ & 48.6 & 7.09 & 50.31 & & \\
\hline
\end{tabular}


Table 1 indicated that there was a significant difference in the mean score of experimental and control group. Further the experimental group performed better than control group.

\section{Findings}

The calculated t-value was 6.2 is greater than the tabulated value i.e. 1.9 at $\mathrm{p}<.05$ and $\mathrm{df}=118$. It shows that the difference between two groups is significant. It also indicates that there is a significant difference in the mean score of experimental and control group. Further the experimental group performed better than control group see table 4.1.

The standard deviation of the marks achieved by the students of experimental group is 5.58 and for the control group it is 7.09 which show that the experimental group's standard deviation is smaller than that of control group. The experimental group performance is more consistent. (Table 4.1)

The mean score (marks achieved in the terminal examination conducted by (AIOU) of experimental group was 55.78 while mean score for the control group was 48.6. The mean score 55.78 is much higher than the mean score 48.6 which shows that the experimental group performed well and the tutorial is effective see table 4.1.

\section{Conclusion and recommendations}

Computer based instruction (multimedia tutorial) techniques are more helpful than face to face tutorial. Performance of the students in the experimental group was better than the control group. The study recommended that the tutorial should be used as a supplement to the printed material in distance education. Multimedia tutorial techniques may be used along with face to face tutorial.

\section{References}

[1] Asan, A., (2003). 'School experience course with multimedia in teacher education' Journal of Computer Assisted Learning (2003) 19, 21-34.

[2] Bennett, S., Maton, K. \& Kervin, L. (forthcoming, 2008). The 'digital natives' debate: A critical review of the evidence, British Journal of Educational Technology.

[3]Boling, N. C., \& Robinson, D. H. (1999). Individual study, interactive multimedia, or cooperative learning: Which activity best supplements lecture-based distance education? Journal of Educational Psychology, 91(1), 169.

[4] Cope, B., Kalantzis, M. (Ed). (2009). Ubiquitous Learning. University of Illinois: USA ISBN: 978-0-25207680-0

[5] Gene, T.S., \& Judith, V.B., (1997). Distance Learning: The Shift to Interactivity.
[6] Gilbert, S.W. (1995). Why distance education? A special bulletin. American Association for Higher Education, 48.

[7] Iskander, M.F., Catten, J.C., Jones, A., Jameson, R., and Balcells, A. (1995) "Interactive Multimedia Lessons for Education," Proceedings, IEEE Microwave and Optoelectronics Conference, Vol. 2, 1995, pp. 693-700

[8]Koehler, W., \& Blair, V. (2003). Distance education in library and information science discipline: the Valdosta State University Case. Informing science in SITE-Where Parallels Intersect, 294-300.

[9] Kruse, K., Keil, J. (2000). Technology-based Training. San Francisco: Jossey-Bass/Pfeiffer.

[10] Mayer, R. E. \& Moreno, R. (2003). Nine Ways to Reduce Cognitive Load in Multimedia Learning, Educational Psychologists 38(1), 43-52.

[11]Mayer, R. E. (2001). Multimedia Learning. New York: Cambridge University Press.

[12] Meier S. (1988) An exploratory study of a computerassisted alcohol education program. Computers in Human Services. 1988;3:111-121.

[13] Natarajan, M. (2005). Innovative teaching techniques for distance education, Communication of the IIMA 2005 volume 5 issue 4 .

[14] Randy, G. (2000). 'Theoretical Challenges for Distance Education in the 21st Century: A Shift from Structural to Transactional Issues' International Review of Research in Open and Distance Learning c ISSN: 14923831, Vol. 1, No. 1 (June 2000).

[15] Sangi, A.N. (2005). Engineering Quality Learning through ICT an AIOU Model for Online Education and Research, ICDE International Conference on Open Learning and Distance Education, New Delhi, November 2005.

[16] Sangi, N. (2009). Access Strategy for Blended Elearning: An AIOU Case Study. Journal of the Research Center for Educational Technology (RCET), volume 5 N.2.

[17] Tannenbaum, R. S. (1998) Theoretical foundations of multimedia. New York: Computer Science Press.

[18] Thorpe, M., (2005). The impact of ICT on lifelong learning. In C. McIntosh \& Z. Varoglu (Eds.) Perspectives on distance education: Life-long learning in distance higher education. Vancouver: Commonwealth of Learning/ UNESCO.

[19] Types of Tutorials, retrieve from website http://www.mccoyin.com accessed on March 14, 2008.

[20] UNESCO, (2002). Open and Distance learning: Trend, Policy and Strategy Considerations, Division of Higher Education, Paris UNESCO. 
[21] UNESCO. (2002). Teacher Education Guidelines: Using Open and Distance Learning Education Sector, Higher Education Division, Teacher Education Section UNESCO Paris

[22] Wang, Q. (2007). Designing a computer supported system for multimedia curriculum development in Shanghai. Published online 15 September 2006 Association for Educational Communications and Technology 2006. 